\title{
A Ba-free sealing glass with a high CTE and excellent interface stability optimized for SOFC/SOEC stack applications
}

Ritucci, llaria; Agersted, Karsten; Zielke, Philipp; Wulff, Anders Christian; Khajavi, Peyman; Smeacetto, Federico; Sabato, Antonio G.; Kiebach, Ragnar

Published in:

International Journal of Applied Ceramic Technology

Link to article, DOI:

10.1111/ijac.12853

Publication date:

2018

Document Version

Peer reviewed version

Link back to DTU Orbit

Citation (APA):

Ritucci, I., Agersted, K., Zielke, P., Wulff, A. C., Khajavi, P., Smeacetto, F., Sabato, A. G., \& Kiebach, R. (2018). A Ba-free sealing glass with a high CTE and excellent interface stability optimized for SOFC/SOEC stack applications. International Journal of Applied Ceramic Technology, 15(4), 1011-1022. https://doi.org/10.1111/ijac.12853

\section{General rights}

Copyright and moral rights for the publications made accessible in the public portal are retained by the authors and/or other copyright owners and it is a condition of accessing publications that users recognise and abide by the legal requirements associated with these rights.

- Users may download and print one copy of any publication from the public portal for the purpose of private study or research.

- You may not further distribute the material or use it for any profit-making activity or commercial gain

- You may freely distribute the URL identifying the publication in the public portal 
MISS ILARIA RITUCCI (Orcid ID : 0000-0001-5070-7264)

DR KARSTEN AGERSTED (Orcid ID : 0000-0002-5270-7441)

DR RAGNAR KIEBACH (Orcid ID : 0000-0002-4619-3894)

Article type : Special Issue Article

\section{A Ba-free sealing glass with a high CTE and excellent interface stability optimized for SOFC/SOEC stack applications}

Ilaria Ritucci ${ }^{a}, *$, Karsten Agersted $^{\mathrm{a}}$, Philipp Zielke ${ }^{\mathrm{a}}$, Anders Christian Wulff ${ }^{\mathrm{a}}$, Peyman Khajavi ${ }^{\mathrm{a}}$, Federico Smeacetto ${ }^{b}$, Antonio G. Sabato ${ }^{b}$ and Ragnar Kiebach ${ }^{a}$

${ }^{a}$ Department of Energy Conversion and Storage, Technical University of Denmark, Ris $\varnothing$ campus, Frederiksborgvej 399, DK-4000 Roskilde, Denmark

${ }^{\mathrm{b}}$ Department of Applied Science and Technology, Politecnico di Torino, Corso Duca degli Abruzzi 24, 10129, Italy

* Corresponding author, mail: ilarit@dtu.dk

\section{Abstract}

A new glass-ceramic composition containing $\mathrm{Si}, \mathrm{Mg}, \mathrm{Ca}, \mathrm{Na}, \mathrm{Al}, \mathrm{Zr}$ and $\mathrm{B}$ is presented here as sealant for planar SOFCs/SOECs, with the aim of joining the metallic interconnect (Crofer22APU) to the solid oxide cell (YSZ electrolyte or CGO barrier layer). Characteristic temperature, thermo-mechanical properties and compositional variations are reviewed and discussed by thermal analyses and in situ

This article has been accepted for publication and undergone full peer review but has not been through the copyediting, typesetting, pagination and proofreading process, which may lead to differences between this version and the Version of Record. Please cite this article as doi: 10.1111/ijac.12853

This article is protected by copyright. All rights reserved. 
$\mathrm{XRD}$, in order to design and optimize the sealing profile and reduce the residual porosity. The glass after heat treatment partially devitrifies into augite and nepheline with residual glass phase of around 64.3\%; after crystallization the glass-ceramic sealant has a CTE of $12.8 \times 10^{-6} \mathrm{~K}^{-1}$ and it is compliant with the other materials typically used for stack components. . This work shows that the developed glass-ceramic can successfully join the ceramic cell with the Crofer22APU (pre-oxidized and alumina coating), proven by tests on small and large-scale samples. No signs of unwanted reactions at the glass-metal and the glass-cell interface are observed and sufficient gas tightness is achieved.

\section{KEY WORDS}

Solid oxide fuel cell, glass-ceramics, synthesis, thermal analysis

\section{Introduction}

The rise in electricity consumption and the consequent need for sustainable energy is constantly driving research toward the development of new renewable energy conversion technologies. Solid oxide fuel/electrolyses cells (SOFC/SOEC) are considered as one of the promising choices for clean energy production because of their high efficiency and versatility for either mobile or stationary power production ${ }^{1,2}$. SOFCs are electrochemical devices, which convert the chemical energy of a fuel (hydrogen or hydrocarbons) and an oxidant (air or oxygen) into electricity and heat without combustion and particle emissions. Nevertheless, the commercialization of SOFCs is still hindered by critical issues with durability and cost of installation. Durability issues stem from both moderate degradation rates of active electrodes and specific issues of material selection and combination of materials that can tolerate rapid fluctuations in operating temperatures ${ }^{3}$. Cell and interconnect components in SOFC-stacks are commonly sealed using glass or glass-ceramic sealants, c.f. Fig. 1, for

This article is protected by copyright. All rights reserved. 
which the adhesion and more importantly thermal expansion have to be tailored to an almost perfect match with the joining partners to avoid a build-up of thermally induced stress, when a stack is cooled down from sealing or operating temperature to room temperature.

Glasses and glass-ceramics are relatively easily applied to the stack components by one of several techniques: screen-printing, tape casting, or extrusion. The sealing process is normally carried out by a heat treatment at temperatures higher than the glass transition, which allows the glass-based sealant to flow and wet the parts to be sealed. This step, in controlled temperature-time conditions, determines the glass devitrification and the final properties of the sealant. Several glass compositions for sealing ceramic cells and metallic interconnects are reported in literature ${ }^{4-10}$. In general, alkaline earth-containing glasses have a desirable high coefficient of thermal expansion (CTE), but, especially for Sr and Ba containing glasses, also a tendency to react with chromium (contained in the steel/interconnect) leading to the formation of chromates at the interface has been reported ${ }^{11-15}$. These chromate layers have a very high CTE $\left(>20 \times 10^{-6} \mathrm{~K}^{-1}\right)^{16}$ causing significant weakening of the seal and delamination. For this reason, the use of barium-free glasses is becoming popular to avoid the formation of chromates such as $\mathrm{BaCrO}_{4}{ }^{17}$. The glass presented in this work contains both $\mathrm{Na}$ and $\mathrm{Ca}$, which can as well lead to the formation of chromates at the interface. For that reason, a protective coating towards the steel will be included.

A suitable glass composition for this application is chosen according to (i) the CTE of the auxiliary stack components (the ceramic cell and the metallic interconnect) and (ii) the glass transition temperature of the glass. During the sealing process, glasses will normally react with metallic counterparts, e.g. Crofer22APU, a high-temperature ferritic stainless steel by ThyssenKrupp VDM, Germany, through redox-type reactions. A typical counteraction is either to coat the metal or to select less aggressive glass compositions. The latter will add significant limitations to the choice of glass. Hence, two different surface modifications have been used in the present work; the formation

This article is protected by copyright. All rights reserved. 
of an oxide scale $\left(\mathrm{Cr}_{2} \mathrm{O}_{3} /(\mathrm{Mn}, \mathrm{Cr})_{3} \mathrm{O}_{4}\right)$ on the steel by pre-oxidation and a commercial alumina coating (AlumiLok $^{\mathrm{TM}}$, Nexceris, USA).

The glass presented here is designed to work in intermediate-temperature SOFCs stacks $\left(700-900^{\circ} \mathrm{C}\right)$. The new glass composition, hereafter-labelled "V11 glass", is an evolution of the V9 glass, which has been developed at Politecnico di Torino by Sabato et al. ${ }^{7}$ and further optimized of the heat treatment described in this work were carried out at the Technical University of Denmark. The change in composition from $\mathrm{V} 9$ is motivated by the low value of its CTE, equal to $9.52 \times 10-6 \mathrm{~K}^{-1}$ (300$500^{\circ} \mathrm{C}$ ), resulting in a different quantity of $\mathrm{Na}$ and $\mathrm{Ca}$ proposed for the $\mathrm{V} 11$. This new system is designed to reduce the mismatch of the CTEs between the components and limit the consequent formation of thermal stresses during operation. The thermal characterization and the sintering behaviour of the glass are presented; the compatibility with the different substrates was also studied and considered.

\section{Experimental}

\subsection{Materials and synthesis}

The composition of the $\mathrm{V} 11$ glass in wt.\% is: $46.37 \% \mathrm{SiO}_{2}, 13 \% \mathrm{MgO}, 14.34 \% \mathrm{CaO}, 9.26 \% \mathrm{Na}_{2} \mathrm{O}, 8.34 \%$ $\mathrm{Al}_{2} \mathrm{O}_{3}, 2.92 \% \mathrm{ZrO}_{2}$, and $5.76 \% \mathrm{~B}_{2} \mathrm{O}_{3}$. The sealant, based on the $\mathrm{V} 11$, was produced as a glass by melting the precursors of the oxides (oxides and carbonates, Table 1) in a platinum crucible at $1300^{\circ} \mathrm{C}$ for 2 hours; the glass was than quenched in water. For the thermal characterization and use during application of the sealant smaller particles with a size of around $7 \mu \mathrm{m}$ were produced using of a planetary ball mill (Retsch PM 1000). The characteristic particle sizes were $d_{10} 1 \mu \mathrm{m}, d_{50} 7 \mu \mathrm{m}, d_{90}$ 25-30 $\mu \mathrm{m}$, measured with a Beckman Coulter LS I3 320 Laser Diffraction Particle Size Analyzer. Larger drops of glass ("bulk") were used for dilatometric measures.

This article is protected by copyright. All rights reserved. 
For sealing tests, two relevant substrates were used, i.e. sheet metal plates and solid oxide cells, to simulate the components presented in Fig. 1.The metal plates were made of a ferritic stainless steel, Crofer22APU (ThyssenKrupp, Germany) ${ }^{18}$ with two different surface modifications: AlumiLok (Nexceris, USA) ${ }^{19,20}$ and pre-oxidation obtained at $900^{\circ} \mathrm{C}$ for 50 hours in air. The cells used were inhouse produced multi-layer tape-casted anode-supported half-cells, which consisted of a NiO-YSZ (yttria-stabilized zirconia) support layer, a thin NiO-YSZ active anode layer, a dense layer of YSZ and in some cases a ceria-gadolinia (CGO) barrier layer ${ }^{21}$.

\subsection{Characterization of the glass and glass-ceramic}

Differential thermal analysis (DTA) (Netzsch 404 PC) measurements were performed on the glass powder at $5^{\circ} \mathrm{C} / \mathrm{min}$ from room temperature to $1300^{\circ}$. The characteristic temperatures extrapolated from the measurements were evaluated at the onset and/or peak temperatures using the commercial Proteus software provided (Netzsch). The glass transition temperature (Tg) was determined using the inflection of the relevant part of the DTA curve. Hot stage microscopy analyses (HSM) (TOMMI, Fraunhofer) were carried out on compacted glass powder pellets from room temperature to $1300^{\circ} \mathrm{C}$ at $5^{\circ} \mathrm{C} / \mathrm{min}$ in static air. The pellets are typically cylindrical shaped, and the data recording is based on the projected image of the sample during the experiment. Dilatometry measurements (DIL) (Netzsch, DIL 402 PC/4) were performed on a drop of glass, as casted, and on a glass-ceramic pellet at a heating rate of $5^{\circ} \mathrm{C} / \mathrm{min}$ to evaluate the coefficient of thermal expansion (CTE) and the dilatometric softening point $\left(T_{s}\right)$. The measurements were carried out from room temperature to $1050^{\circ} \mathrm{C}$ with a "softening point detection" (set with the Netzsch Software) to avoid the melting of the sample in the instrument's chamber. To obtain the devitrification of the pellet, a pressed bar of glass powder ( $4 \mathrm{~mm}$ length) is sintered with a specific thermal profile (see Results section).

This article is protected by copyright. All rights reserved. 
Chemical and microstructural analyses were performed using scanning electron spectroscopy (SEM) and energy-dispersive $x$-ray spectroscopy (EDS) (TM3000 Hitachi). The crystallization behavior was investigated by in-situ XRD (XRD Bruker D8) from room temperature to $800^{\circ} \mathrm{C}$ with in a 2theta range from $10^{\circ}-90^{\circ}$ to extrapolate the crystallization temperatures of the crystalline phases. The experiment was carried out on a platinum/rhodium stage in air.

Rietveld refinement of the XRD patterns of glass-ceramic powders was carried out in order to evaluate the content of amorphous phase and the proportion between the crystalline phases. The glass-ceramic powders were obtained by grinding a pellet of glass, which was sintered with the sealing profile presented in the Results section. As an internal standard 20 wt.\% of zincite (zinc oxide, Alfa Aesar) were added to the powders. Two measurements were carried out, one on pure zincite and another one on the glass-ceramic powder mixed with $20 \%$ of zincite.

All the XRD files were analyzed with X'Pert HighScore Plus (Panalytical) and the Rietveld refinement was carried out using the WINPOW software ${ }^{22}$.

\subsection{Sealing of the samples and characterization}

The sealant was applied onto the metal substrates as a paste by screen-printing (DEK 248 CERD). The paste was prepared from $70 \%$ of glass powder and $30 \%$ of organic paste components (solvent, binder, surfactant and plasticizer; confidential composition). The powders needed to have a $d_{50}$ particle size distribution lower than $10 \mu \mathrm{m}$ for being suitable for screen-printing. After printing, the green paste was heat-treated at $120^{\circ} \mathrm{C}$ in air for 1.5 hours and at $300^{\circ} \mathrm{C}$ for 1.5 hours to burn out the organic compounds. The thickness of the layer was determined to be $55 \mu \mathrm{m}$ (Cyberscan Vantage). Surface modified metal plates were sealed to the cell in a furnace with a hydraulic piston used to apply a load of $16.7 \mathrm{~N} / \mathrm{cm}^{2}$ to advice the sintering of the glass. These samples had a dimension of 2 $\mathrm{cm} \times 2 \mathrm{~cm}$ (metal substrate and half-cell), and were prepared for SEM analyses by vacuum 
embedding in epoxy resin (Epofix, Struers) and cut in the center to analyze the cross-sections and the interfaces between the glass and the joining partners. The samples were then ground with SiC paper with a polishing machine. While bigger samples with a cell of $11 \times 11 \mathrm{~cm}^{2}$ were then prepared with the same procedure to test the seal under conditions occurring in a stack of industrially relevant size.

\subsection{Leak test setup}

To determine the gas tightness of the seal, the pressure dependent diffusion of air through the glass seal was measured. An SOC half-cell $\left(11 \times 11 \mathrm{~cm}^{2}\right)$ was sealed to an AlumiLok ${ }^{\mathrm{TM}}$ coated Corfer $22 \mathrm{APU}$ frame with the CGO layer facing the seal. The frame had an opening of $9 \times 9 \mathrm{~cm}^{2}$. A $1 \mathrm{~cm}$ wide V11 seal was printed around the opening, resulting in a $40 \mathrm{~cm}^{2}$ seal area (Fig. $2 \mathrm{~b}$ ). The assembly was then clamped into a test house forming closed cavities on both sides of the frame (Fig. 2a). Each cavity had a gas in- and outlet. Silicon rubber gaskets were used to ensure gas tightness in the clamping area. By means of mass flow controllers (MKS GE50A-series, range: 500 SCCM) a defined flow of air (MFC 1) was fed to one cavity (air side) and nitrogen (MFC 2) to the other (nitrogen side). The outlets of the cavities were connected to a pressure gauge each ( $p_{1}$ and $p_{2}$, Omega Engineering, absolute pressure transducer, $3500 \mathrm{mbar}, 0.05 \%$ accuracy) measuring the absolute pressure of the individual cavities and a differential pressure gauge ( $\Delta \mathrm{p}$, Omega Engineering, bidirectional pressure transducer, $350 \mathrm{mbar}, 0.05 \%$ accuracy) measuring the pressure difference between the air and the nitrogen side. Downstream the pressure gauges metering valves (Swagelok, SS-4MG-MH) were installed to adjust the air and fuel side's pressure. For measuring large leak rates > 5 SCCM two mass flow meters (MFM 1 and MFM 2, MKS GE50A-series) were installed. Small leak rates of air from the air to the nitrogen side were quantified by means of measuring the oxygen partial pressure of the nitrogen side outlet stream with an in-house built $\mathrm{pO}_{2}$-sensor. Assuming that the measured oxygen partial pressure equals

This article is protected by copyright. All rights reserved. 
$p_{O_{2}, \text { measured }}=\frac{p_{\mathrm{O}_{2}}^{0} \cdot J_{\text {leak }}+p_{\mathrm{O}_{2} \text { in } \mathrm{N}_{2}} \cdot J_{N_{2}, \text { inlet }}}{J_{\text {leak }}+J_{N_{2}, \text { inlet }}}$,

the leak rate of air $J_{\text {leak }}$ can be calculated to

$J_{\text {leak }}=\frac{\frac{\left(p_{O_{2}, \text { measured }}-p_{O_{2} \text { in } N_{2}}\right)}{p_{O_{2}}^{0}} \cdot J_{N_{2}, \text { inlet }}}{1-\frac{p_{O_{2}, \text { measured }}}{p_{O_{2}}^{0}}}$,

with $p_{O_{2}}^{0}$ as the oxygen partial pressure in the supplied air, $p_{O_{2}}$ in $N_{2}$ as the oxygen partial pressure in the supplied nitrogen and $J_{N_{2} \text {, inlet }}$ as the inlet flow rate of nitrogen (MFC 2).

\section{Results}

\subsection{Dilatometry analyses of the glass and glass-ceramics}

The dilatometric curves of the amorphous glass and the glass-ceramic are shown in Fig. 3, the CTEs to characterise the expansion of the glass-ceramic below the glass transition temperature, $\mathrm{Tg}$, were extrapolated considering the linear part of the curve between 200 and $450^{\circ} \mathrm{C}$. The CTE of the amorphous glass (as casted) resulted in $9.6 \times 10^{-6} \mathrm{~K}^{-1}\left(200^{\circ} \mathrm{C}-450^{\circ} \mathrm{C}\right)$ and the curve shows a dilatometric softening point $\left(T_{d}\right)$ at $635^{\circ} \mathrm{C}$. The glass-ceramic pellet obtained from pressed glass powders was heat-treated at $800^{\circ} \mathrm{C}$ for 1 hour, and the displayed a CTE of $12.8 \times 10^{-6} \mathrm{~K}^{-1}\left(200^{\circ} \mathrm{C}\right.$ $450^{\circ} \mathrm{C}$ ). Moreover, the dilatometric curve presents a deviation from linearity with an onset at $495^{\circ} \mathrm{C}$ and a softening at $999^{\circ} \mathrm{C}$.

\subsection{HSM and DTA: sintering behavior}

Sintering and devitrification behavior of the V11 glass were evaluated from HSM and DTA experiments, and the resultant graph is presented in Fig. 4a.

A significant shrinkage of the specimen was observed at temperatures higher than $652^{\circ} \mathrm{C}$ (first shrinkage, $\left.T_{F S}\right)$. The volume decrease continued until reaching the first maximum shrinkage $\left(T_{M S 1}\right)$ at

This article is protected by copyright. All rights reserved. 
$700^{\circ} \mathrm{C}$. At this temperature, the shrinkage corresponds to $18 \%$. A second sintering maximum shrinkage is found at $\mathrm{T}_{\mathrm{MS} 2}=830^{\circ} \mathrm{C}$, showing a volume decrease of $22 \%$.

More information can be extrapolated from the HSM measure, the shapes of the sample (shown in

Fig. 4b) are related to some characteristic fixed points which corresponds to a specific temperature $\left(\right.$ Table 2) ${ }^{23}$.

The method proposed by Pascual et al. ${ }^{23}$ was adopted to predict the viscosity of the glass at the characteristic temperatures. The data retrieved from the HSM curve (Table 2) can be plotted, as in Fig. 5, in a viscosity-temperature curve. The fitting of these points gives a trend line for predicting the viscosity of the glass at a certain temperature.

In conclusion, the glass exhibited a two-stage shrinkage behavior. The first shrinkage $\mathrm{T}_{\mathrm{MS} 1}$ occurred before the crystallization peak (shown in the DTA, black curve in Fig. 4a), while a second shrinkage, the $\mathrm{T}_{\mathrm{MS2}}$, occurred slightly before the onset of the crystallization. Moreover, a volume increase of the glass-ceramic can been seen after reaching $900^{\circ} \mathrm{C}$ (red curve Fig. 4a), this should not influence the sealing process since it will be held at temperature below the crystallization peak.

\subsection{In situ-XRD investigation}

To investigate the crystallisation behaviour of the V11 glass during the sealing process, in-situ XRD measurements were carried out. In these experiments, the glass powder was exposed to the same thermal profile used for sealing experiments described in 3.3.1. Here, the sample was heated up to $600^{\circ} \mathrm{C}$ from room temperature (RT) with a heating rate of $100^{\circ} \mathrm{C} / \mathrm{h}$, and was held at that temperature for $1 \mathrm{~h}$. Afterwards the sample was heated up to $700^{\circ} \mathrm{C}$ with $100{ }^{\circ} \mathrm{C} / \mathrm{h}$, further heating to $800{ }^{\circ} \mathrm{C}$ was done with $50{ }^{\circ} \mathrm{C} / \mathrm{h}$ and a final hold of $1 \mathrm{~h}$ was carried out. XRD patterns were recorded at RT, after reaching $700{ }^{\circ} \mathrm{C}, 750{ }^{\circ} \mathrm{C}$ and $800{ }^{\circ} \mathrm{C}$. Two additional XRD patterns were recorded at $800{ }^{\circ} \mathrm{C}$ after a holding time of $30 \mathrm{~min}$ and $60 \mathrm{~min}$. The results are presented in Fig. 6.

This article is protected by copyright. All rights reserved. 
In the XRD measurements conducted up to $700{ }^{\circ} \mathrm{C}$ (Fig. $6 \mathrm{f}$, e) only the diffraction peaks of the platinum substrate and the amorphous halo are recognizable, showing that the glass was still amorphous at this temperatures, as expected. The XRD measurement performed at $750^{\circ} \mathrm{C}$ (Fig. $6 \mathrm{~d}$ ) shows the peaks corresponding to augite $\left(\mathrm{Ca}\left(\mathrm{Mg}_{0.70} \mathrm{Al}_{0.30}\right)\left(\mathrm{Si}_{1.70} \mathrm{Al}_{0.30}\right) \mathrm{O}_{6}, \mathrm{Al}\right.$ - substituted diopside $)$ and nepheline ( $\mathrm{NaAlSiO}_{4}$, sodium aluminum silicate) were identified. Further heating up to $800{ }^{\circ} \mathrm{C}$ did not lead to the formation of new crystalline phases, but the peak intensity for the different phases increased, indicating ongoing crystallisation going along with a disappearance of the glassy phase (Fig. 6c). The patterns recorded at $800^{\circ} \mathrm{C}$ after $30 \mathrm{~min}$ and $60 \mathrm{~min}$ (Fig. 6b, a) gave similar results. Compared to the first measurements carried out at $800{ }^{\circ} \mathrm{C}$ the characteristic peaks of the nepheline showed a higher intensity, while the intensity of the peaks corresponding to the augite were comparable for all measurements at $800^{\circ} \mathrm{C}$.

In order to quantify the amounts of the crystalline phases, Rietveld refinements and reference intensity ratio (RIR) methods using zincite as the internal standard were carried out. The details of the refinement of the glass-ceramic sintered at $800^{\circ} \mathrm{C}$ can be found in the supplementary information (Tab. S1, Fig.S1). Results indicate that the phase composition can be described as a mixture of an amorphous phase (64.3 wt\%) and two crystalline phases (28.5 wt\% augite and $7.2 \mathrm{wt} \%$ nepheline).

\subsection{Joining of SOFC components}

In this section, the results from using the V11 glass to join Crofer22APU to YSZ electrolytes and CGO barrier layer of non-reduced half-cells are described. The Crofer22APU used in these experiments was either pre-oxidized or protected by AlumiLok ${ }^{\mathrm{TM}}$ coating. All experiments were performed on samples with a size of $2 \times 2 \mathrm{~cm}$, the chosen joining setup of metallic and ceramic components (Fig. 1) represents the most relevant configurations found in SOFC/SOEC stacks. In section 3.4.1, the 
optimization of the sealing procedure, leading to a reduction of pores in the glass-ceramic sealing and a better adhesion at the interfaces to the joining partners, is presented, while the microstructure of the glass-ceramic seal and a detailed analysis of the different interfaces is presented in section 3.4.2.

\subsubsection{Optimization of the sealing profile}

In total, three different sealing profiles, pressure-temperature, were tested. The initial sealing profile was designed based on the insight gained from DTA and dilatometry experiments. Here, the joining assembly was heated up to $850{ }^{\circ} \mathrm{C}$ with a heating rate of $1.67^{\circ} \mathrm{C} / \mathrm{min}$, held for $2 \mathrm{~h}$ at this temperature, and then cooled down to RT with the same heating rate use during the heating up. During the complete sealing procedure, a constant weight load of $10 \mathrm{~N} / \mathrm{cm}^{2}$ was applied.

SEM images of the cross-sections of the sealed assemblies are shown in Fig. 7a-c. On average, the obtained glass-ceramic sealant had a thickness of $90 \mu \mathrm{m}$. The light grey areas correspond to the crystalline phases formed during the sealing, while the darker grey areas represent the remaining amorphous glass. Both phases were evenly distributed. The adhesion to the YSZ electrolyte as well to the rough Al-coated Crofer22APU was good, i.e. no crack formation or delamination was observed. The densification of the sealant was rather poor, and pores with different sizes and shapes can be clearly observed throughout the complete seal (black areas in Fig. 7d). A quantification based on the contrast of the different phases (Fig. 7d) reveled a rather high porosity of $31 \%$.

In a first attempt to reduce the porosity in the sealant, the sealing temperature was decreased down to $800^{\circ} \mathrm{C}$, and the holding was reduced to $1 \mathrm{~h}$, while heating rates and weight load were kept constant, allowing the sample to remain in a temperature regime were the glass is viscous. The SEM micrograph of the cross-section is shown in Fig. 7b. As for the previous experiment, the glass is partially devitrified, and a distinct separation of the crystalline phases and the residual amorphous

This article is protected by copyright. All rights reserved. 
glass can be observed. The good adhesion at interfaces was maintained and, most importantly, the porosity could be reduced by $40 \%$ down to a total of $18 \%$ (Fig. 7e) by using this sealing profile.

Further reduction of the porosity down to $8 \%$ could be achieved by increasing the weight load up to 16.7 N/cm ${ }^{2}$ and following an optimized sealing profile: $20^{\circ} \mathrm{C}-600^{\circ} \mathrm{C}$ at $100^{\circ} \mathrm{C} / \mathrm{h}, 1 \mathrm{~h}$ holding, $600^{\circ} \mathrm{C}-$ $700^{\circ} \mathrm{C}$ at $100^{\circ} \mathrm{C} / \mathrm{h}, 700^{\circ} \mathrm{C}-800^{\circ} \mathrm{C}$ at $50^{\circ} \mathrm{C} / \mathrm{h}, 1 \mathrm{~h}$ holding and then cooling down. While the microstructure of the glass-ceramic and at the interfaces stayed unchanged, the thickness of the sealing was reduced to $75 \mu \mathrm{m}$, and only small, randomly distributed closed pores are present in sealant (Fig. 7c, f).

\subsubsection{SEM-EDS analysis of the interfaces}

In Fig. 8, the SEM images of the interfaces of the V11 glass-ceramic and a) pre-oxidized Crofer22APU, d) AlumiLok ${ }^{\mathrm{TM}}$ coated Crofer22APU are shown. Comparing the cross-sections of the pre-oxidized and the AlumiLok ${ }^{\mathrm{TM}}$ Crofer22APU (Fig. 8a and d, respectively), it is obvious that the surface roughness of the AlumiLok ${ }^{\mathrm{TM}}$ coated Crofer22APU is much higher. These results indicate that the used coating process heavily roughens the surface of the Crofer22APU alloy. Despite the different surface structure, both samples display a good adherence between the glass-ceramic and the (coated) Crofer22APU alloy, and no cracks, defects or delamination effects can be found (Fig. 8a and b). Differences can be observed in the crystallization behaviour of the V11 glass for the different substrates used. While for the $\mathrm{Al}_{2} \mathrm{O}_{3}$-coated sample, a random orientation of the crystals in the glassceramic was found, a more oriented crystallization was observed when pre-oxidized Crofer22APU was used as joining partner. Additional EDS analyses were carried to investigate a possible $\mathrm{Cr}$ diffusion from the alloys into the glass-ceramic. The corresponding elemental maps and line scans are presented in Fig. 8. For the AlumiLok ${ }^{\mathrm{TM}}$ coated Crofer22APU, a continuous layer of $\mathrm{Al}_{2} \mathrm{O}_{3}$ with a thickness of $0.6 \mu \mathrm{m}-0.9 \mu \mathrm{m}$ separating the glass-ceramic seal and the Crofer22APU alloy was found

This article is protected by copyright. All rights reserved. 
after the sealing process (Fig. 8b, g), indicating that the applied coating was chemically stable and no reactions occurred. Also the $\mathrm{Cr}_{2} \mathrm{O}_{3} / \mathrm{MnCr}_{2} \mathrm{O}_{4}$ double layer with a thickness of $1.5 \mu \mathrm{m}-2.8 \mu \mathrm{m}$ formed during the pre-oxidation of the Crofer22APU remained intact (Fig. $8 \mathrm{~d}, \mathrm{e}$ ), and no reactions with the V11 glass were observed. In both samples, no $\mathrm{Cr}$ enrichment in the glass-ceramic close to the Crofer22APU interface was observed in the elemental mapping (Fig. 8c, f), indicating that no chromates (e.g. $\mathrm{Na}_{2} \mathrm{CrO}_{4}$ or $\mathrm{CaCrO}_{4}$ ) were formed. These results were confirmed by an EDS line scan performed on the sample with the pre-oxidized Crofer22APU (Fig. 8h). A sharp drop in the Cr line indicated that no $\mathrm{Cr}$ diffused from the oxide scale into the sealant. Similar behaviour it is shown in Fig. $8 \mathrm{~g}$ for the AlumiLok ${ }^{\top M}$ coated substrate, where the $\mathrm{Cr}$ line scan is decreasing sharply at the interface between Crofer22APU and the coating (peak in the Al line).

Fig. 9a and b show the interface between the glass-ceramic and YSZ and CGO, respectively. In both cases, excellent adhesion was found, and no cracks or voids were present. In the elemental maps shown in Fig. 9c, no diffusion from elements found in the YSZ electrolyte/CGO barrier layer into the glass or vice versa was observed, indicating a good chemical stability of the joining partners. Additionally, an EDS point analysis of the crystalline phase in the glass-ceramic (light grey, marked "1" in Fig. 9b) and the amorphous phase (dark grey, marked "2" in Fig. 9b) was carried out. According to the point analysis (details can be found in the supplementary information, Tab. S3) the amorphous phase is mainly composed of $\mathrm{Na}, \mathrm{Si}$, and, $\mathrm{Al}$, while the crystals primarily contain $\mathrm{Si}, \mathrm{Ca}$ and $\mathrm{Mg}$; hence this phase can be labelled, in agreement with the XRD result, as augite. It was not possible to identify any nepheline crystals by EDS analysis with the applied resolution, indicating that the crystals are either too small or the signal might overlap with the high content of augite.

This article is protected by copyright. All rights reserved. 


\subsection{Leak test on a cell with industrially relevant size}

For proof-of-concept, a $11 \times 11 \mathrm{~cm}^{2}$ half-cell was sealed onto a Crofer22APU frame (AlumiLok ${ }^{\mathrm{TM}}$ coated). A compression force of $16.7 \mathrm{~N} / \mathrm{cm}^{2}$ was applied at room temperature and kept constant throughout the sealing procedure. The optimized temperature profile described earlier (see 3.3.1) was employed. After the sintering, the sealant was able to seal the cell onto the frame, and no cracks or signs of detachment were observed.

The gas tightness of the seal was investigated with the described leak test setup. Firstly, the partial pressure of oxygen in the supplied nitrogen was determined to be $p_{O_{2} \text { in } N_{2}}=1.23 \mu \mathrm{bar}$. Afterwards, the cell assembly was mounted in the test house. The gas flows for the air and the nitrogen side were set to $500 \mathrm{sccm}$ (standard cubic centimetre per minute). An initial differential pressure of $\Delta p=p_{\text {air side }}-p_{\text {nitrogen side }}=\sim 0.5$ mbar was set, with $p_{\text {air side }}$ at atmospheric pressure, and the setup was left to flush for $24 \mathrm{~h}$ until the measured $p_{O_{2}}$ was constant. The differential pressure $\Delta p$ was stepwise increased to $\sim 20$ mbar. At each step (nine steps) the setup was left to equilibrate and the $p_{\mathrm{O}_{2}}$ of the nitrogen side's outflow was recorded. Throughout the measurements, the measured oxygen partial pressure was constant at $p_{O_{2}}=1.42 \mu$ bar without showing any dependence on the applied differential pressure $\Delta p$. This behaviour indicated a Knudsen diffusion process, which was expected for a leak through a low porosity seal. The oxygen partial pressure corresponds to a very low air leak rate of $1.2 \cdot 10^{5} \mathrm{sccm} / \mathrm{cm}$. It needs to be noted that this value is the combined leak rate through the seal, potential pinholes in the cell and leaks through the rubber gasket of the test house.

This article is protected by copyright. All rights reserved. 


\section{Discussion}

As shown in Fig. 3, the glass and the glass-ceramic have relatively high CTEs of 9.6 and $12.8 \times 10^{-6} \mathrm{~K}^{-1}$, respectively. The increase has been ascribed to the presence of the nepheline and augite phases ${ }^{24,25}$, but since the crystalline phases only account for $\sim 36 \mathrm{wt} \%$ of the entire microstrucure it indicates that the crystalline skeleton or network must be coherent and inter-grown. This hypothesis is supported by the lack of resiliency above $\mathrm{Tg}$, as seen for the glass-ceramic in the Fig. 4 . The value for the technical coefficient of expansion (T-CTE) between room temperature and $800^{\circ} \mathrm{C}$ is $13.6 \times 10^{-6} \mathrm{~K}^{-1}$, which is in the desired range for SOFC sealing materials, and is compatible with other materials used in solid oxide cells (e.g. YSZ electrolytes: T-CTE $=10.8 \times 10^{-6} \mathrm{~K}^{-1}, \mathrm{Ni} / \mathrm{YSZ}$ electrodes: $\mathrm{T}-\mathrm{CTE}=12.6 \times 10^{-6}$ $\mathrm{K}^{-1}$ ) and auxiliary stack components like Crofer22APU $\left(\mathrm{T}-\mathrm{CTE}=12.3 \times 10^{-6} \mathrm{~K}^{-1}\right)^{18}$. Compared to previously developed glasses with a comparable chemical composition $\left(\mathrm{Vg}^{7}\right)$ a significant increase in the CTE of $3.3 \times 10^{-6} \mathrm{~K}^{-1}$ was achieved by changing the $\mathrm{Na}$ :Ca ratio. The content of $\mathrm{Na}_{2} \mathrm{O}$ in $\mathrm{V} 9$ and $\mathrm{V} 11$ is $10.3 \%$ wt and $9.26 \% \mathrm{wt}$, respectively. While the content of $\mathrm{CaO}$ in $\mathrm{V} 9$ and $\mathrm{V} 11$ is $9.3 \%$ wt and $14.34 \%$ wt, respectively.

From the HSM curve (Fig. 4) it can be seen that the first shrinkage sets on at $652^{\circ} \mathrm{C}\left(\mathrm{T}_{\mathrm{FS}}\right)$, indicating that the particles started sintering due to viscous flow since the temperature is above the $T_{g}\left(630^{\circ} \mathrm{C}\right)$. While passing the first sintering, which peaked at temperature $\mathrm{T}_{\mathrm{MS} 1}=700^{\circ} \mathrm{C}$, all the larger pores were presumably closed. Another interesting aspect of this graph is that a second shrinkage step, $\mathrm{T}_{\mathrm{MS} 2}$ was also observed at higher temperatures probably due to the amorphous phase left after crystallization, but only the $T_{M S 1}$ is considered when deciding on the sealing temperature of the stack. A two stage shrinkage behavior is already known for glasses from literature ${ }^{7,26}$. The $T_{\text {MS1 }}$ occurred before the crystallization peak (shown in the black DTA curve, Fig. 4), while the $T_{M S 2}$ occurred really close to $T_{x}$. The red HSM curve shows a surprising increase of volume above $900^{\circ} \mathrm{C}$, which is also evident in the dilatometry results presented in Fig. 3. The exact cause for this has not been clarified yet, but it may due to the release of volatile species and consequent pores formation or stem from an additional

This article is protected by copyright. All rights reserved. 
crystallization from the glass in preferred growth directions, e.g. formation of needle-shaped crystals at higher temperatures.

The combination of HSM and DTA can be used to determine the so-called thermal stability of the glass, which can be defined through the Hruby parameter $K_{H}=T_{x}-T_{g} / T_{m}-T_{x}{ }^{27}$, where $T_{x}$ is the onset of the crystallization $\left(850^{\circ} \mathrm{C}\right), \mathrm{T}_{\mathrm{g}}=630^{\circ} \mathrm{C}$ and $\mathrm{T}_{\mathrm{m}}=1175^{\circ} \mathrm{C} . \mathrm{A} \mathrm{K} \mathrm{H}_{\mathrm{H}}$-value above 0.5 indicates a stable glass, and the value, $\mathrm{K}_{\mathrm{H}}=0.68$, derived for the $\mathrm{V} 11$ glass indicates that the sealing process can be successfully undertaken. The sintering ability $\mathrm{S}_{C}$, which is defined as $\mathrm{S}_{\mathrm{c}}=\mathrm{T}_{\mathrm{x}}-\mathrm{T}_{\mathrm{MS}}$ by Lara et al. ${ }^{28,29}$ can also be used to characterize a glass for its sealing performance as it illustrates how independent crystallization and sintering are. The sintering ability for $\mathrm{V} 11$ is $\mathrm{S}_{\mathrm{c}}=150^{\circ} \mathrm{C}$, which provides a temperature range below $T_{x}$ in which sealing can be successfully done. In the very same temperature range, nucleation processes exhibit maximum rates and by subsequently keeping the sealant at temperatures at or slightly above $T_{x}$, formation of the glass-ceramic microstructure will be as fast and efficient as possible. Concluding this discussion, sealing with a slow heating through the temperature range between $700^{\circ} \mathrm{C}$ and $850^{\circ} \mathrm{C}$ and subsequent annealing at $850^{\circ} \mathrm{C}$, will provide the fastest route to a glass-ceramic sealant. It is however for practical reasons desirable to maintain a high degree of sealant resiliency during the sealing process for the various counterparts to attain optimum bonding and the final sealing temperature, chosen at $800^{\circ} \mathrm{C}$, reflects how these arguments are brought together.

The sealing profile was optimized (see result section 3.4.1), and the porosity in the glass-ceramic was reduced from $31 \%$ to $8 \%$ by reducing the sealing temperature and increasing the weight load during the sealing process. In the first sealing experiments, a sealing temperature of $850^{\circ} \mathrm{C}$ was used. As shown in Fig. 7d, the glass-ceramic sealant contained a relatively high number of pores, which can lead to gas leaks and reduce the overall bonding strength between the stack components. These non-spherical pores seen in Fig. $7 d$ could be a result of a relatively fast crystallization that hindered the viscous flow/distribution of the glass. Interestingly, this correlation is related to the sinter-

This article is protected by copyright. All rights reserved. 
crystallization behaviour of the glass-ceramic. These results are in agreement with the observations from DTA/HSM and suggest that the sealing temperature was too close to the crystallisation temperature (Fig. 4).

By lowering the sealing temperature to $800^{\circ} \mathrm{C}$, which is approximately half-way between the $\mathrm{T}_{\mathrm{MS} 1}$ and before the $T_{x}$, a lower porosity of the glass would be expected, which was indeed confirmed by the observed microstructures demonstrating a more dense layer of glass visible in the SEM micrographs of cross-sections shown in Fig. 7b,e. Based on data presented in Fig. 5, it is possible to extrapolate the viscosity values, and the optimum value at the sealing temperature should be between $10^{6}-10^{9} \mathrm{dPa} \cdot \mathrm{s}^{29}$, from other sources is $10^{6.6} \mathrm{dPa} \cdot \mathrm{s}^{9,30}$. The extrapolated values of the viscosity are $10^{6.3} \mathrm{dPa} \cdot \mathrm{s}$ and $10^{6} \mathrm{dPa} \cdot \mathrm{s}$ at $800^{\circ} \mathrm{C}$ and $850^{\circ} \mathrm{C}$ respectively.

Some pores are still present in the sealant, but the origin of these is not fully understood. It has been suggested that since the paste used for the screen printing contains an organic vehicle, not all the binders where fully oxidised during the heat-up and started to partly reduce the glass after an initial sintering and pore-closure between the glass particles, thus leaving entrapped $\mathrm{CO}_{2}$ in pores. To avoid and solve this inconvenience, a step of 1 hour at $600^{\circ} \mathrm{C}$, below the $\operatorname{Tg}$ of the glass $\left(630^{\circ} \mathrm{C}\right)$, was added in the heat treatment. The maximum temperature for the sealing was maintained at $800^{\circ} \mathrm{C}$ and to further force the viscous flow and sealant densification, a slightly higher load was applied at this temperature. Further, limiting the maximum temperature to $800^{\circ} \mathrm{C}$ prevents an excessive crystal growth, which can potentially hinder the sintering by viscous flow, as previously showed. The resultant sealant is indeed thinner and with a lower porosity left, cf. Fig. 7c,f.

The microstructure of the sealant, c.f. the cross-sections in Fig. 8-9, appears as a glass-ceramic with amorphous and crystalline phases. The point analyses (supplementary information, Tab. S3) confirmed the presence of different phases, which were identified by the XRD analysis and the Rietveld refinement. The amorphous phase (64.3\%) is the dark grey area in Fig. 9 (Point 1 of the point analysis) compared to the initial composition of the glass, is rich in $\mathrm{Na}, \mathrm{Al}$ and $\mathrm{Zr}$ and poor in $\mathrm{Ca}$

This article is protected by copyright. All rights reserved. 
and $\mathrm{Mg}$, which are mainly retrieved in the augite, the predominant crystalline phase according to the Rietveld refinement (28.5\%). In accordance hereto, the dilatometric measurement of the glassceramic (Fig. 3) exhibits the $\mathrm{Tg}$ of the amorphous phase left at a lower temperature $\left(495^{\circ} \mathrm{C}\right.$ ) than observed from the pristine glass. The presence of the augite, Al-substituted diopside, might indicate a certain stability of the glass, since the diopside "family" is known for being stable in terms of crystal growth and consequently not to influence the CTE after long time heat treatment ${ }^{31}$; this will be evaluated with further experiments in future works.

The interfaces between the glass and the cell (both YSZ and CGO) and the surface modified (coating/pre-oxidized) Crofer22APU substrates were investigated and no particular signs of interface reactions were detected. The glass was providing a good adhesion and the efficiency of the surface modifications used for the Crofer22APU were proved. No chromates were detected at the interface or in the sealant, only at the edges of the substrates, where no coating/oxide scale provided protection.

By applying the latest sealing profile, a larger cell $(\sim 11 \times 11 \mathrm{~cm})$ was sealed onto a frame and tested for in the leak test setup as shown in Fig. 2. A stably freestanding seal was achieved that even after weeks did not show any signs of delamination and exhibited a gas tightness, i.e. low enough leak rate appropriate for application in SOC stacks.

\section{Conclusion}

A barium-free glass-ceramic sealant (V11) containing $\mathrm{Si}, \mathrm{Al}, \mathrm{Ca}, \mathrm{Mg}, \mathrm{B}, \mathrm{Zr}$ and $\mathrm{Na}$ was designed and successfully tested for joining and sealing planar SOFC/SOECs components. The composition was optimized to achieve a CTE $\left(12.810^{-6} \mathrm{~K}^{-1}\right)$ complying with the other components in a SOFC stack. The final glass-ceramic seal was obtained after optimization of the sealing profile by means of the thermal (HSM, DIL, DTA) and in-situ XRD analyses presented in this work. The glass-

This article is protected by copyright. All rights reserved. 
ceramic sealant exhibited a residual glass phase of around $64.3 \mathrm{wt} \%$ after sealing, shown by XRD and SEM/EDS analysesThe devitrification lead to the formation of two crystalline phases, augite (Al-diopside) and nepheline, which are responsible for the mechanical stability of the glass, also at higher temperatures. The interface reactions towards the metallic components, was tested on Crofer22APU substrates applying two different protective surface modifications, preoxidation and AlumiLok ${ }^{\mathrm{TM}}$ coating, for which neither chromate formation was detected in the glass or at the glass-metal interface, at least after the sealing process. Lastly, V11 was not only successfully tested on small test samples, but also by sealing a cell with industrially relevant dimensions $\left(11 \times 11 \mathrm{~cm}^{2}\right)$ to a AlumiLok ${ }^{\mathrm{TM}}$ coated Crofer22APU frame, which gave satisfactory results in terms of leak rates.

\section{Acknowledgement}

The authors like to thank P. H. Nielsen, L. Knudsen and S. Jamali (POLITO) for technical assistance.

\section{References}

1. Carrette L, Friedrich K a, Stimming U. Fuel Cells - Fundamentals and Applications. Fuel Cells. 2001;1(1):5-39. doi:10.1002/1615-6854(200105)1:1<5::AID-FUCE5>3.0.CO;2-G.

2. Timurkutluk B, Timurkutluk C, Mat MD, Kaplan Y. A review on cell/stack designs for high performance solid oxide fuel cells. Renew Sustain Energy Rev. 2016;56:1101-1121. doi:10.1016/j.rser.2015.12.034.

3. Boccaccini DN, Sevecek O, Frandsen HL, et al. Determination of the bonding strength in solid oxide fuel cells' interfaces by Schwickerath crack initiation test. J Eur Ceram Soc. 2017;37(11):3565-3578. doi:10.1016/j.jeurceramsoc.2017.04.018.

This article is protected by copyright. All rights reserved. 
4. Reddy AA, Tulyaganov DU, Kharton V V., Ferreira JMF. Development of bilayer glass-ceramic SOFC sealants via optimizing the chemical composition of glasses - a review. J Solid State Electrochem. 2015;19(10):2899-2916. doi:10.1007/s10008-015-2925-5.

5. Yang Z, Meinhardt KD, Stevenson JW. Chemical Compatibility of Barium-CalciumAluminosilicate-Based Sealing Glasses with the Ferritic Stainless Steel Interconnect in SOFCs. J Electrochem Soc. 2003;150(8):A1095. doi:10.1149/1.1590325.

6. Smeacetto F, Salvo M, Ferraris M, Cho J, Boccaccini AR. Glass-ceramic seal to join Crofer 22 APU alloy to YSZ ceramic in planar SOFCs. J Eur Ceram Soc. 2008;28(1):61-68. doi:10.1016/j.jeurceramsoc.2007.05.006.

7. Sabato AG, Cempura G, Montinaro D, et al. Glass-ceramic sealant for solid oxide fuel cells application: Characterization and performance in dual atmosphere. J Power Sources. 2016;328:262-270. doi:10.1016/j.jpowsour.2016.08.010.

8. Meinhardt K, Kim D, Yang G, Chou M. Glass Sealing of Solid Oxide Fuel Cells.

9. Naylor MO, Jin T, Shelby JE, Misture ST. Galliosilicate glasses for viscous sealant in solid oxide fue cell stacks: Part I: Compositional design. 2013.

10. Kiebach R, Agersted K, Zielke P, Ritucci I, Brock MB, Hendriksen PV. A Novel SOFC/SOEC Sealing Glass with a Low SiO 2 Content and a High Thermal Expansion Coefficient. ECS Trans. 2017;78(1):1739-1747. doi:10.1149/07801.1739ecst.

11. Chou YS, Stevenson JW, Singh P. Effect of pre-oxidation and environmental aging on the seal strength of a novel high-temperature solid oxide fuel cell (SOFC) sealing glass with metallic interconnect. J Power Sources. 2008;184(1):238-244. doi:10.1016/j.jpowsour.2008.06.020.

This article is protected by copyright. All rights reserved. 
12. Chou YS, Stevenson JW, Singh P. Effect of aluminizing of Cr-containing ferritic alloys on the seal strength of a novel high-temperature solid oxide fuel cell sealing glass. J Power Sources. 2008;185(2):1001-1008. doi:10.1016/j.jpowsour.2008.09.004.

13. Chou YS, Stevenson JW, Xia GG, Yang ZG. Electrical stability of a novel sealing glass with (Mn,Co)-spinel coated Crofer22APU in a simulated SOFC dual environment. J Power Sources. 2010;195(17):5666-5673. doi:10.1016/j.jpowsour.2010.03.052.

14. Mahapatra MK, Lu K. Glass-based seals for solid oxide fuel and electrolyzer cells - A review. Mater Sci Eng R Reports. 2010;67(5-6):65-85. doi:10.1016/j.mser.2009.12.002.

15. Zhang T, Brow RK, Fahrenholtz WG, Reis ST. Chromate formation at the interface between a solid oxide fuel cell sealing glass and interconnect alloy. J Power Sources. 2012;205:301-306. doi:10.1016/j.jpowsour.2012.01.043.

16. Mahapatra MK, Lu K. Seal glass compatibility with bare and (Mn,Co)3O4 coated Crofer 22 APU alloy in different atmospheres. J Power Sources. 2011;196(2):700-708. doi:10.1016/j.jpowsour.2010.07.084.

17. Smeacetto F, Salvo M, Ferraris M, Casalegno V, Asinari P, Chrysanthou A. Characterization and performance of glass-ceramic sealant to join metallic interconnects to YSZ and anodesupported-electrolyte in planar SOFCs. J Eur Ceram Soc. 2008;28(13):2521-2527. doi:10.1016/j.jeurceramsoc.2008.03.035.

18. VDM-Metals. VDM ${ }^{\circledR}$ Crofer 22 APU. 2010;(Werkstoffdatenblatt Ausgabe Januar):10. http://www.vdmmetals.com/fileadmin/user_upload/Downloads/Data_Sheets/Datenblatt_VDM_Crofer_22_A PU.pdf.

This article is protected by copyright. All rights reserved. 
19. Kidner NJ. ALUMILOK TM COATINGS: ENHANCED HIGH TEMPERATURE PERFORMANCE FOR COMMERCIAL STEELS. www.nexceris.com. Accessed November 1, 2016.

20. Choi JP., Chou YS, Stevenson JW. Reactive Air Aluminization. PNNL. 2011;(October).

21. Hauch A, Brodersen K, Chen M, Mogensen MB. Ni/YSZ electrodes structures optimized for increased electrolysis performance and durability. Solid State Ionics. 2016;293:27-36. doi:10.1016/j.ssi.2016.06.003.

22. Brink BK, Ståhl K, Christiansen TL, Somers MAJ. The ternary Fe-C-N system: Homogeneous distributions of nitrogen and carbon. J Alloys Compd. 2017;690:431-437. doi:10.1016/j.jallcom.2016.08.130.

23. Pascual MJ, Durán A, Prado MO. A new method for determining fixed viscosity points of glasses. Phys Chem Glas. 2005;46(5):512-520.

24. Kôzu S, Ueda J. Thermal Expansion of Augite. Inst Mineral Petrol Econ Geol Tohoku Imp Univ Sendai. 1934;(2):87-90.

25. Hovis GL, Crelling J, Wattles D, et al. Thermal expansion of nepheline - kalsilite crystalline solutions. Mineral Mag. 2003;67(3):535-546. doi:10.1180/0026461036730115.

26. Goel A, Reddy AA, Pascual MJ, Gremillard L, Malchere A, Ferreira JMF. Sintering behavior of lanthanide-containing glass-ceramic sealants for solid oxide fuel cells. J Mater Chem. 2012;22(19):10042-10054. doi:10.1039/c2jm16300d.

27. Hrubý A. Evaluation of glass-forming tendency by means of DTA. Czechoslov J Phys. 1972;22(11):1187-1193. doi:10.1007/BF01690134.

28. Lara C, Pascual MJ, Prado MO, Durán A. Sintering of glasses in the system RO-Al2O3-BaOSiO2 ( $\mathrm{R}=\mathrm{Ca}, \mathrm{Mg}, \mathrm{Zn}$ ) studied by hot-stage microscopy. Solid State lonics. 2004;170(3-4):201208. doi:10.1016/j.ssi.2004.03.009.

This article is protected by copyright. All rights reserved. 
29. Lara C, Pascual MJ, Durán A. Glass-forming ability, sinterability and thermal properties in the systems RO-BaO-SiO2 (R = Mg, Zn). J Non Cryst Solids. 2004;348:149-155. doi:10.1016/j.jnoncrysol.2004.08.140.

30. Flugel A, Dolan MD, Varshneya AK, et al. Development of an improved devitrifiable fuel cell sealing glass I. Bulk properties. J Electrochem Soc. 2007;154(6):B601-B608. doi:10.1149/1.2728291.

31. Reddy AA, Tulyaganov DU, Pascual MJ, et al. Diopside-Ba disilicate glass-ceramic sealants for SOFCs: Enhanced adhesion and thermal stability by Sr for Ca substitution. Int J Hydrogen Energy. 2013;38(7):3073-3086. doi:10.1016/j.ijhydene.2012.12.074.

This article is protected by copyright. All rights reserved. 
Table 1 V11 chemical composition.

\begin{tabular}{|c|c|c|c|}
\hline & $\begin{array}{l}\text { Chemical composition } \\
\text { (wt\%) }\end{array}$ & & $\begin{array}{l}\text { Raw materials for } 100 \\
\mathrm{~g} \text { of glass }(\mathrm{g})\end{array}$ \\
\hline $\mathrm{SiO}_{2}$ & 46.37 & $\mathrm{SiO}_{2}$ & 46.37 \\
\hline MgO & 13 & $\mathrm{MgCO}_{3}$ & 27.55 \\
\hline $\mathrm{CaO}$ & 14.34 & $\mathrm{CaCO}_{3}$ & 25.6 \\
\hline $\mathrm{Na}_{2} \mathrm{O}_{3}$ & 9.26 & $\mathrm{Na}_{2} \mathrm{CO}_{3}$ & 15.83 \\
\hline $\mathrm{Al}_{2} \mathrm{O}_{3}$ & 8.34 & $\mathrm{Al}_{2} \mathrm{O}_{3}$ & 8.34 \\
\hline $\mathrm{ZrO}_{2}$ & 2.92 & $\mathrm{ZrO}_{2}$ & 2.92 \\
\hline $\mathrm{B}_{2} \mathrm{O}_{3}$ & 5.76 & $\mathrm{H}_{3} \mathrm{BO}_{3}$ & 10.23 \\
\hline
\end{tabular}

Table 2 characteristic fixed viscosity points and related temperatures.

\begin{tabular}{lll} 
& $\begin{array}{l}\text { Temperature } \\
\left({ }^{\circ} \mathrm{C}\right)\end{array}$ & $\log [\eta$ (Poise) $]$ \\
\hline $\mathrm{T}_{\mathrm{FS}}$ & 652 & 9,1 \\
$\mathrm{~T}_{\mathrm{MS}}$ & 700 & 7,8 \\
$\mathrm{~T}_{\mathrm{D}}$ & 769 & 6,3 \\
$\mathrm{~T}_{\mathrm{B}}$ & 825 & 5,4 \\
$\mathrm{~T}_{\mathrm{HB}}$ & 1110 & 4,1 \\
$\mathrm{~T}_{\mathrm{F}}$ & 1176 & 3,4
\end{tabular}

This article is protected by copyright. All rights reserved. 

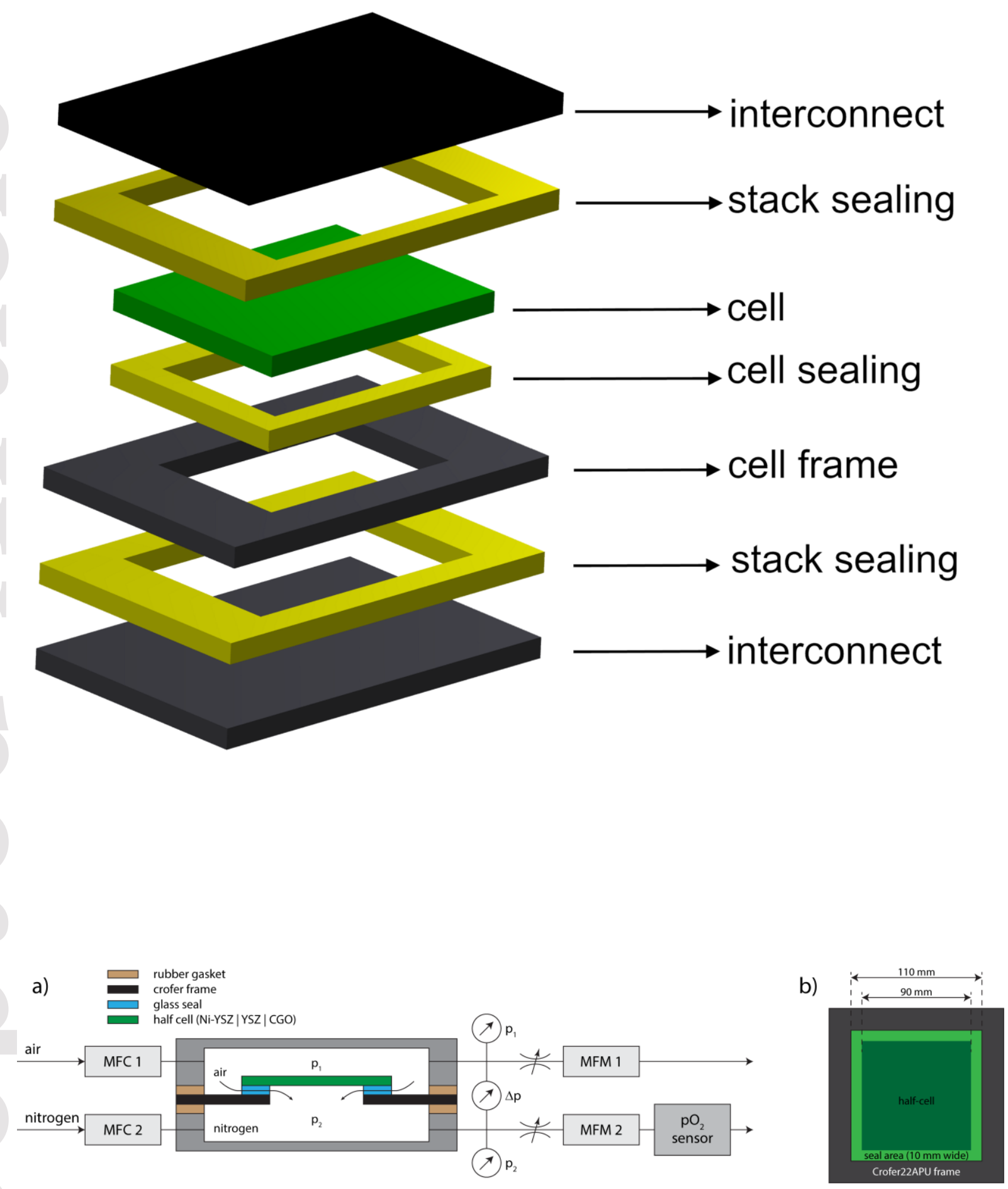




This article is protected by copyright. All rights reserved. 


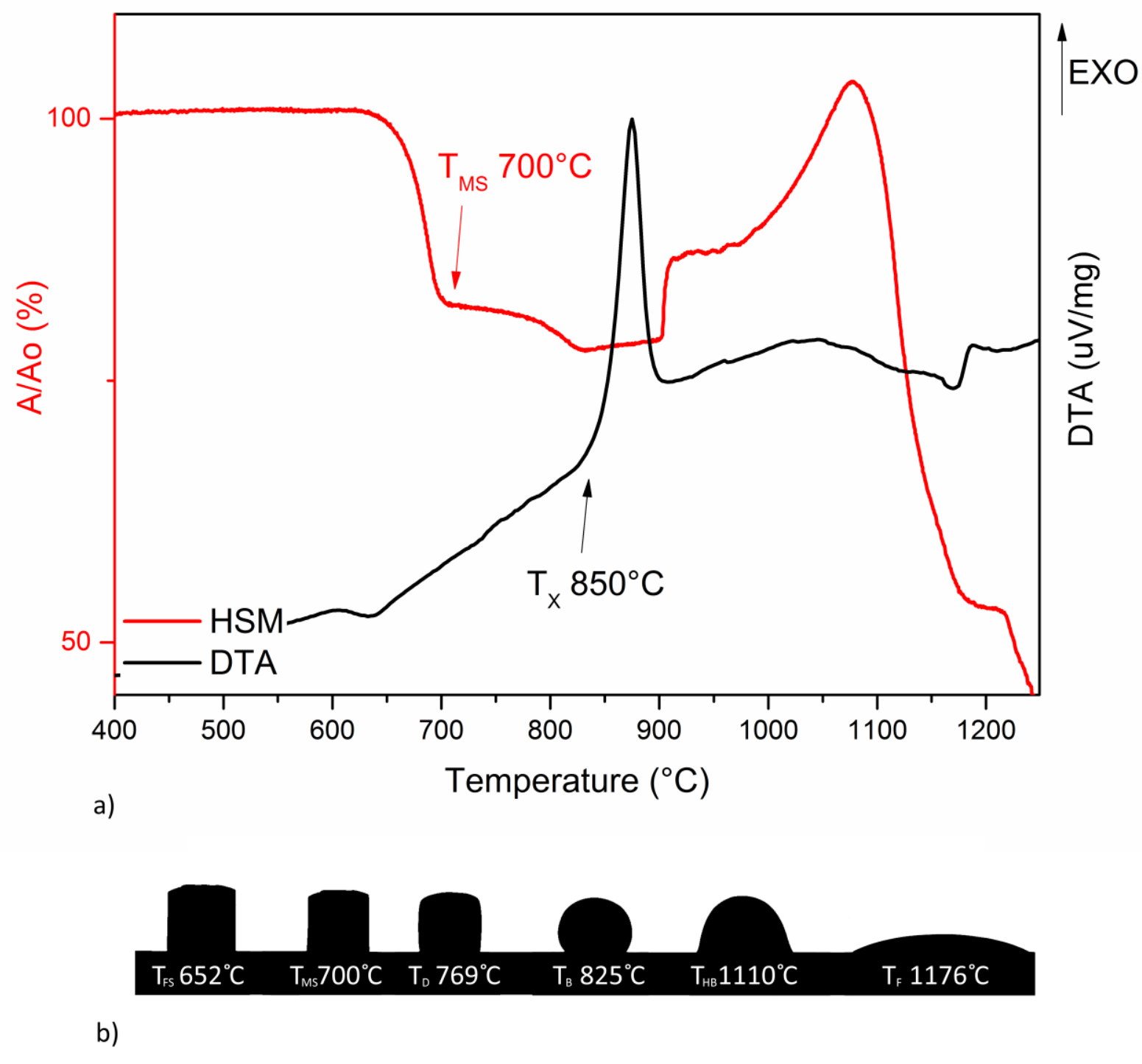

This article is protected by copyright. All rights reserved. 




This article is protected by copyright. All rights reserved. 


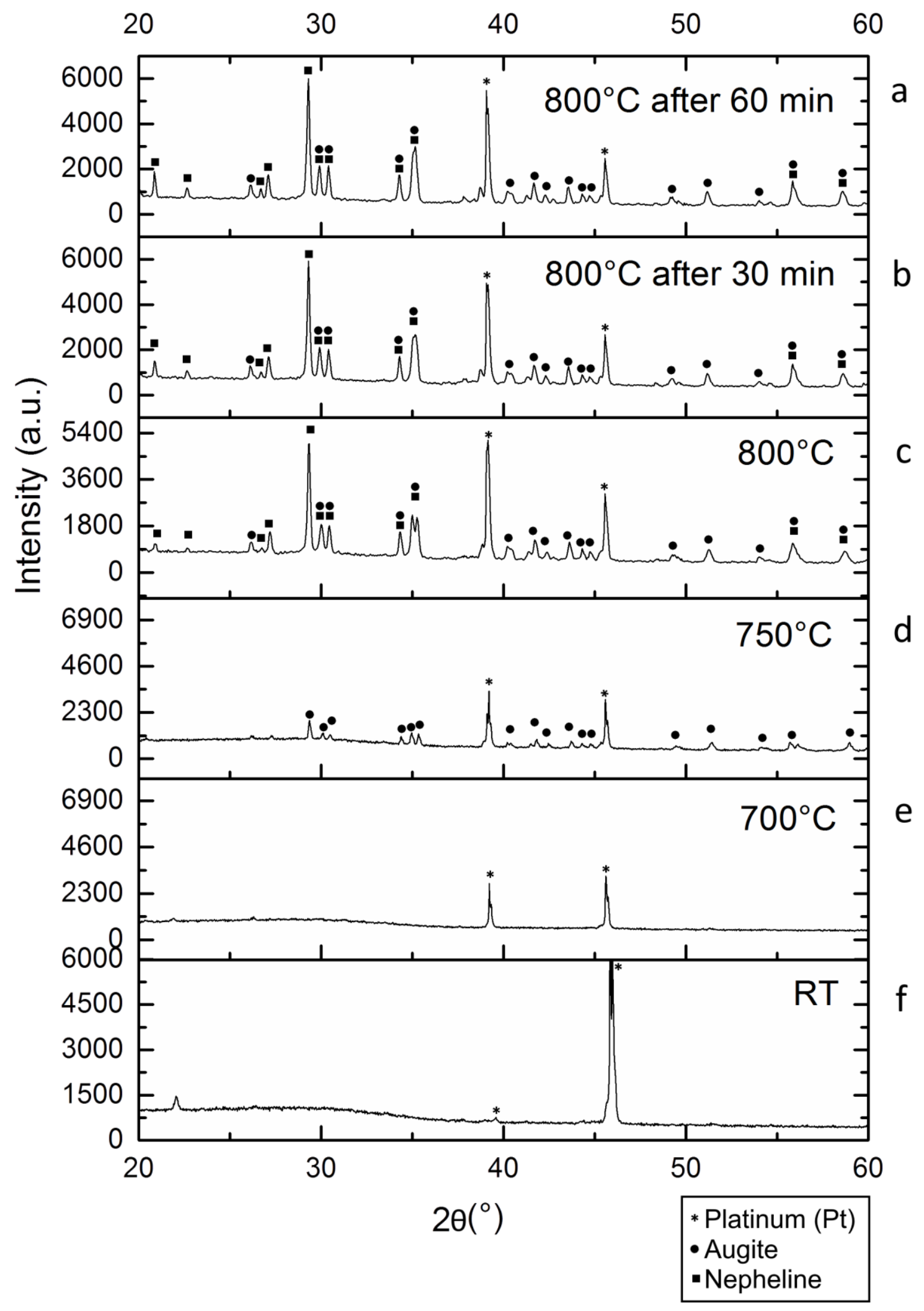

This article is protected by copyright. All rights reserved. 



a)
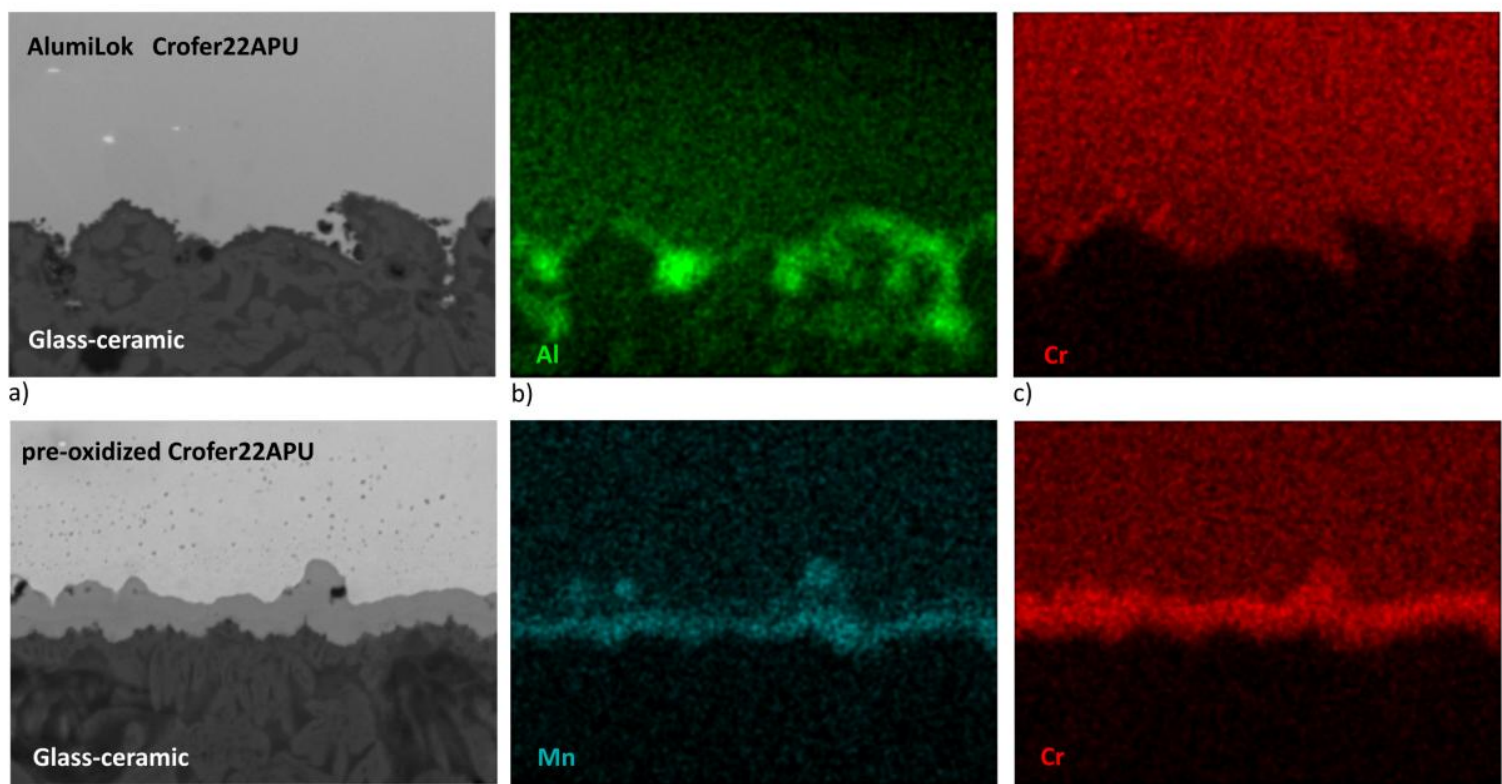

d) counts
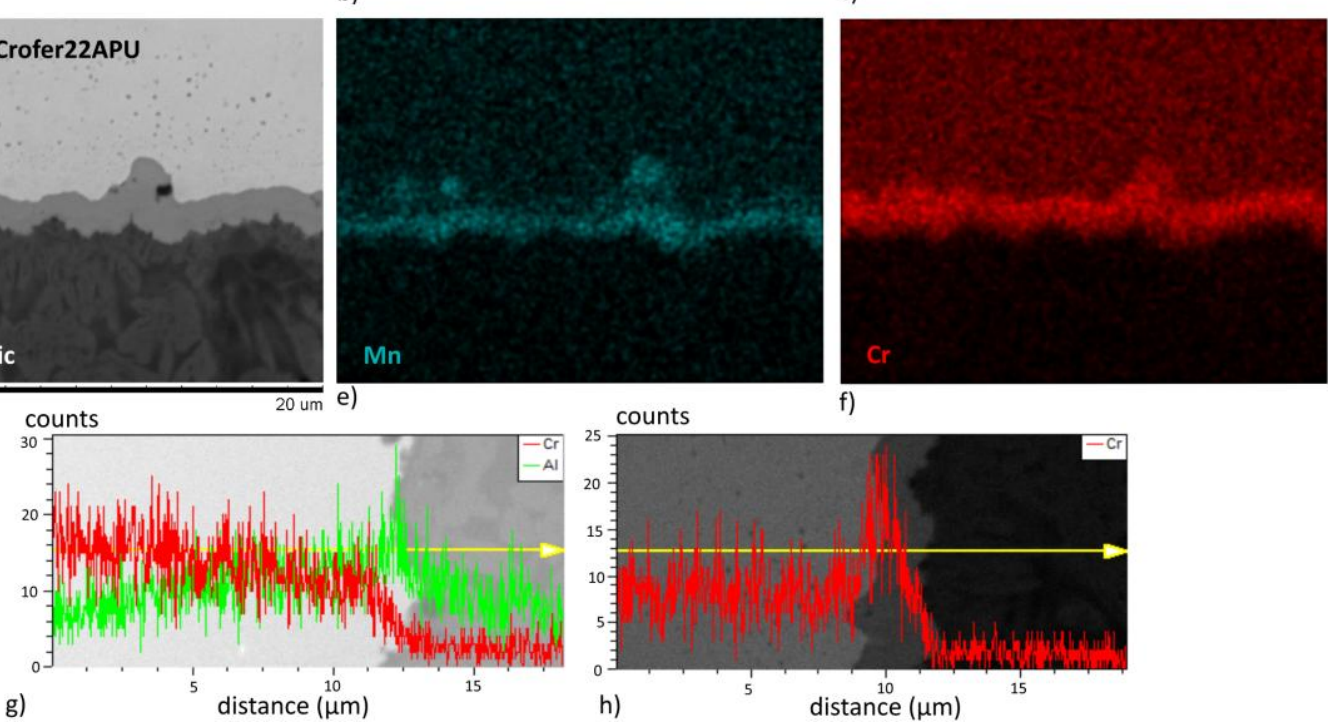

This article is protected by copyright. All rights reserved. 



a)

b)
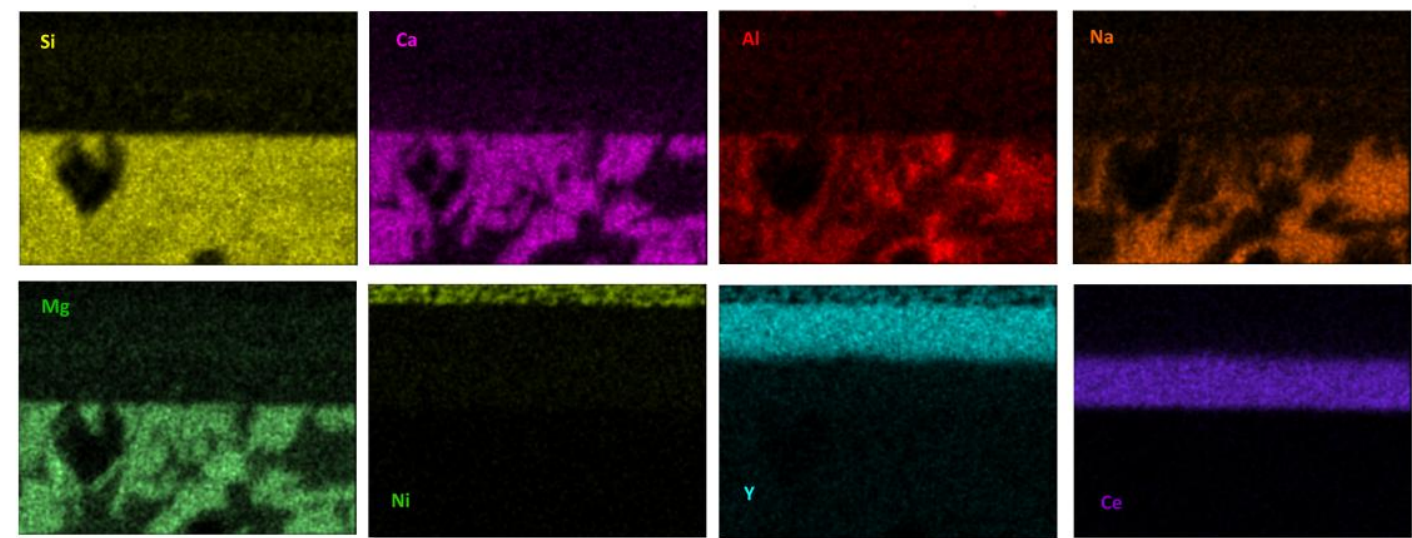

c)

This article is protected by copyright. All rights reserved. 